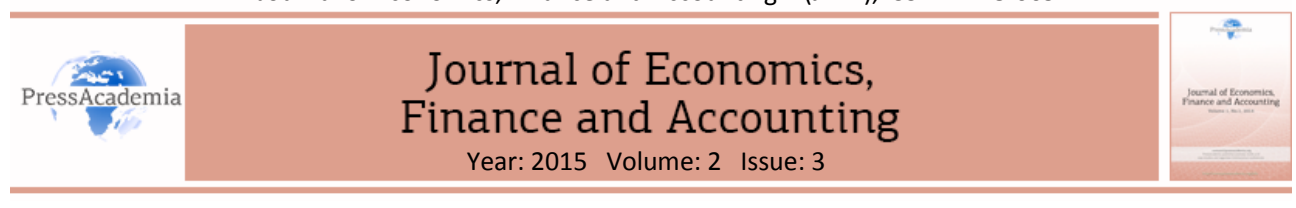

\title{
PREDICTION OF CORPORATE BANKRUPTCY: EVIDENCE FROM WEST AFRICAN'S SMES
}

\author{
DOI: 10.17261/Pressacademia.2015312959
}

Kokou Adalessossi ${ }^{1}$

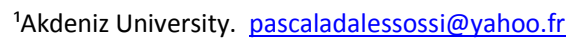

\section{Keywords}

Z-score model, PCA, bankruptcy, liquidity, West Africa.

JEL Classification G10, G33, M10

\begin{abstract}
Bankruptcy is a legal proceeding in which a corporation has become insolvent and therefore cannot pay its obligations. The purpose of this paper is to assess the default risk or to predict bankruptcy of some public firms listed on the stock Exchange Securities (BRVM) of West African Economic and Monetary Union (WAEMU) and on the Ghana Stock Exchange (GSE). 34 companies from different sectors and sizes have taken place in this study. The main purpose is to measure the performance of these companies that constitute the backbone of the regional economy whether banks or investors can have confidence on them to finance their activities. To perform this study, the 2013 dataset financial statements were taken from the website of the two stock exchanges. Then, Discriminant function named Z-scores model of Altman, financial ratio analysis, and the Principal Component Analysis were used. The results of this study show that out of the 34 public companies, only 8 companies have had good financial performance, and on which financial institutions or investors can have confidence for financing or investment. Among all the companies, the most best performing company was listed in Ghana Stock Exchange. The most problem encountered by $85 \%$ of the 34 companies was the liquidity problem. This study will permit investors and banks to put regards on these companies on one side, and to awaken those companies which have realized bad financial performances on the other side.
\end{abstract}

\section{INTRODUCTION}

Small and medium sized enterprises are reasonably considered the backbone of the economy of many countries all over the world (Adalessossi. K. and Utku .B.D, 2015). For OECD members (2002), the percentage of SMEs out of the total number of firms is greater than 97 percent. In the US, SMEs provide approximately 75 percent of the net jobs added to the economy and employ around 50 percent of the private workforce, representing 99.7 percent of all employers. In the West African Economic and Monetary Union zone, SMEs provide approximately more than 70 percent of the net jobs added to the economy and employ around 60 percent of the private workforce, representing 90 percent of all employers .Thanks to the simple structure of most SMEs, they can respond quickly to changing economic conditions and meet local customers' needs, growing sometimes into 
large and powerful corporations or failing within a short time of the firm's inception. From a credit risk point of view, SMEs are different from large corporate for many reasons. For example, Dietsch and Petey (2004) analyze a set of German and French SMEs and conclude that they are riskier but have a lower asset correlation with each other than large businesses.

Small or large companies, public or private need necessary funds to run their activities. At the point where there insufficient means to continue the business, the management will have to liquidate the company asset, pay or re reimburse its debtors and walk away with the remains, if any.

In situation there are insufficient funds to repay all debtors in full, the company, at some point in time, will be declared bankrupt. At this situation any bank or investor could not accepted to provide funds for it in order to make it stand up. Consequently, a curator will liquidate the assets and distribute the remaining financials to the debtors in rights fully. In both situations, the firm will stop to exist. It is crucial to able to predict corporate failure. Credit risk or default risk concerns the financials state that a company is in. An assessment of a company's financial situations permits us, within certain boundaries, to establish what the future reserve for it, and by doing so to determine the risk of doing business with the company. Credit risk measurement has evolved dramatically over 25 past years. The question arises how credit risk may be determined. Is about financial ratios, about share prices and thus market value asset compared to book value of assets, or there more to it?

Some 35 years ago, most financial institutions relied almost exclusively on subjective analyses or so-called banker "expert" systems to assess the credit risk on corporate loans. Essentially, bankers used information on various borrower characteristic such as borrower character (reputation), capital (leverage), capacity (volatility of earning) and collateral, to reach a largely subjective judgment (i.e., that of an expert as to whether or not to grant credit. This was the so-called $4 C^{\prime}$ 's of credit. Many-more objectively based-approaches to quantify default risk have been developed and refined ever since. Out of these objective models, it can be mentioned 4 multivariate accounting-based-scoring models such as the logit model, the linear probability model, the probit model ( probability unit) and the discriminant analysis model that is the most commonly used.

The ability of SMEs (especially those involving innovations and new technologies) to access alternate sources of capital like equity finance, angel funds/risk capital is extremely limited. At present, there is almost negligible flow of equity capital into this sector, which poses serious challenge to development of knowledge-based industries, particularly those that are promoted by first-generation entrepreneurs with the requisite expertise and knowledge. Venture /Risk capital is, therefore, often a more appropriate financing instrument for high-growth-potential and start-up SMEs. However, access to this type of financing is often not available to them. In the absence of alternate sources of finance, the SMEs' reliance on debt finance is very high. The availability of debt finance, however, is not adequate as viability of these small units is a major issue. Besides, the high reliance on debt, combined with high cost of credit adversely impacts the financial viability of startups, particularly in the initial years, thereby threatening their long-term survival and sustainability. 
The financial literature on small business lending focuses thoroughly on the determinants and costs to credit access (e.g. Berger and Udell, 1996). There is, however, little research examining the repayment behavior of small firms that actually receive loans (Glennon and Nigro 2005). Moreover, the literature on business credit scoring (e.g. Katz et al., 1985) focuses on large businesses with very few studies that explore credit scoring for small businesses.

The rest of the study is as following. We propose in section II to identify the variables that are relevant when predicting loan events or corporate/SMEs default risk in the literature review. In section III we describe the data and methodology, and set out results and discussions in the section IV before to conclude and make suggestion for the future study in the final section.

\section{LITERATURE SURVEY}

\subsection{Studies on SMEs}

More recently, the new Basel Accord for bank capital adequacy (Basel II) has seen many analysts focus on the SME segment (see for example Schwaiger (2002)), Saurina and Trucharte (2004), Udell (2004), Berger (2004), Jacobson et al. (2004), and Altman and Sabato (2005)). Actually, criticisms have been raised by governments and SME associations that high capital charges for SMEs could lead to credit rationing of small firms and, given the importance of these firms in the economy, could reduce economic growth. The aforementioned studies have dealt with the problem of the possible effects of Basel II on bank capital requirements, but the problem of modeling credit risk specifically for SMEs has either not been addressed or only briefly considered. Other authors have focused on the difficulties and the potentials of small business lending, investigating the key drivers of SMEs.

\subsection{Studies with Default Prediction}

The literature about default prediction methodologies is substantial. Many authors during the last 50 years have examined several possible realistic alternatives to predict customers' default or business failure. The seminal works in this field were Beaver (1967) and Altman (1968), who developed univariate and multivariate models to predict business failures using a set of financial ratios. Beaver (1967) used a dichotomous classification test to determine the error rates a potential creditor would experience if he classified firms on the basis of individual financial ratios as failed or non-failed. He used a matched sample consisting of 158 firms (79 failed and 79 non-failed) and he analyzed 14 financial ratios. Altman (1968) used a multiple discriminant analysis technique (MDA) to solve the inconsistency problem linked to the Beaver's univariate analysis and to assess a more complete financial profile of firms. His analysis drew on a matched sample containing 66 manufacturing firms (33 failed and 33 non-failed) that filed a bankruptcy petition during the period 1946-1965. Altman examined 22 potentially helpful financial ratios and ended up selecting five as providing in combination the best overall prediction of corporate 
bankruptcy. The variables were classified into five standard ratios categories, including liquidity, profitability, leverage, solvency and activity ratios.

For many years thereafter, MDA was the prevalent statistical technique applied to the default prediction models. It was used by many authors (Deakin (1972), Edmister (1972), Blum (1974), Eisenbeis (1977), Taffler and Tisshaw (1977), Altman et al. (1977), Bilderbeek (1979), Micha (1984), Gombola et al. (1987), Lussier (1995), Altman et al. (1995)). However, in most of these studies, authors pointed out those two basic assumptions of MDA are often violated when applied to the default prediction problems. Moreover, in MDA models, the standardized coefficients cannot be interpreted like the slopes of a regression equation and hence do not indicate the relative importance of the different variables. Considering these MDA's problems, Ohlson (1980), for the first time, applied the conditional logit model to the default prediction's study.

The logit model yields a score between zero and one which conveniently gives the probability of default of the client. Lastly, the estimated coefficients can be interpreted separately as the importance or significance of each of the independent variables in the explanation of the estimated PD. After the work of Ohlson (1980), most of the academic literature (Zavgren (1985), Gentry et al. (1985), Keasey and Watson (1987), Aziz et al. (1988), Platt and Platt (1990), Ooghe et al. (1995), Mossman et al. (1998), Lizal (2002), Becchetti and Sierra (2002)) used logit models to predict default. Despite the theoretic differences between MDA and logit analysis, studies (see for example Lo (1985)) show that empirical results are quite similar in terms of classification accuracy.

\subsection{Bank Risks and Lending Technologies}

It is generally agreed that banks that specialize on commercial lending are in the risk business. Among the several types of risks faced by these institutions, credit risk is the one of interest in this study because of its potential social impact that can affect shareholders, managers, lenders, suppliers and clients, among others (Emmel, 2003). Credit risk arises from nonperformance by a borrower. It may arise from either an inability or an unwillingness to perform in the precommitted contracted manner (Santomero, 1997). The finance literature highlights that although difficult to eliminate completely, credit risk is diversifiable. For a government bank, this task may be somewhat difficult as social objectives and policy programs such as stimulating entrepreneurial activity of a specific industry sector may produce fewer opportunities for diversification.

The literature on business lending recognizes two main approaches used in the lending process: transactional lending and relationship lending. Under transaction lending, due diligence and contract terms are based on information relatively easily available at the time of origination (Berger, Klapper and Udell, 2001). Transactions lending technologies are primarily based on hard quantitative data that may be observed and verified at the time of credit origination, such as financial ratios calculated from certified audited financial statements, information provided by credit bureaus and information on accounts receivable, among others According to Berger and Udell (2006), transaction lending can be subdivided in more specific categories, which include: financial statement lending, small business credit scores and asset based lending, factoring and trade credit. According to 
the authors individual transactions technologies are distinguished from one another by the type and source of hard information that is main basis for the underwriting decision.

On the contrary, under relationship-lending information is gathered by the lender beyond the transparent data available in financial statements and other sources readily available during the origination process (Berger, Klapper and Udell, 2001). Mainly, it is based on soft qualitative data gathered throughout the relationship, more specifically through contact over time with the borrower, the business's suppliers and customers, and through the interaction with the local community. Also, relationship lending considers payment and receipts history from past loans, deposits and other services provided by the financial institution. From the different types of transaction technologies, small business credit scores have surfaced throughout the past decade as an alternative to relationship lending, which predominated the lending market of opaque SMEs. In the past few years, banks have increased the use of different types of scoring models in order to satisfy the demand of this unique segment. Credit scoring is a transaction lending technology that helps organizations decide whether or not to grant credit to consumers who apply to them. Several authors have supported the usefulness of Small Business Credit Scores, particularly as it can be used as a decision support system (Tsaih et al. 2004). Other purposes identified in the literature include: pricing loans based on degree of risk, differential handling of late payments and delinquencies, differential handling of collections based on outcome predictions, estimating the amount of profit an account is likely to generate, identifying applicants who may be candidates for other services and targeting prospective customers (Barefoot, 1996; Friedland, 1996;)

\subsection{Bank Risks Ratio Analysis and Failure Prediction Models}

There has been extant literature that empirically assesses the usefulness of financial ratio analysis and business failure. For example, Altman (1968), Beaver (1966) and Edmister (1972) have applied sophisticated statistical techniques to financial data of firms and performance. These have mainly focused on the development of Bankruptcy Prediction Models. In general, research has indicated that ratio analysis is useful at predicting failure of medium and large firms. However, it is important to notice that the financial Ratio that has been found useful in predicting failure differ from study to study (Dimitris et al., 1996). Moreover studies assessing the usefulness of ratio analysis in predicting small business failures have been lacking, and to our best knowledge they are seldom use to predict small business loan events, such as severe delinquencies.

Edmister (1972) empirically tested the usefulness of financial ratio analysis in predicting small business failure. The following ratios were found significant at predicting business failure of small firms: quick ratio, inventory/net working capital, net working capital/total assets, current assets/total debt, total debt/equity, fixed assets/equity, cash flow/current liabilities, current liabilities/equity, inventory/sales, fixed assets/sales, total assets/sales, net working capital/sales, equity/sales, earnings before taxes/sales, earnings before taxes/total assets and earnings before taxes/equity.

In 1988, P.Hutchinson, Meric, \& Meric used Principal Components Analysis (PCA) to identify the financial characteristics of small firms like to achieve quotation on the UK unlisted securities market .In 1992, Laitinen attempted to develop a model to predict 
failure of newly founded firms. He depicted the process of failure for new firms in the following manner: (1) high indebtedness and small size; (2) too slow velocity of capital, too fast growth and poor profitability; (3) unexpected lack of revenue financing, and (4) poor static liquidity and debt service ability. His study showed that it was possible, to some extent, to predict failure of new businesses in the first year after foundation. He found that the best univariate predictors were the following: stockholders capital/total capital, cash flow/net sales and cash flow/total debt.

In a more recent study, Emel et al. (2003) described useful dimensions in financial ratio analysis, which included: liquidity, activity, financial structure, profitability, and growth and funds flow aspects. Although the study recognized the importance of the widely used 5 'Cs of credit - capital, capacity, condition, collateral and character - the authors concentrated their analysis in the following two dimensions: capacity and capital. However, it is important to notice that this study, which employed Data Envelopment Analysis (DEA), considered a sample of industrial manufacturing firms. The benefits and limitations of financial ratio analysis are addressed in a widely used text on managerial finance: Essentials of Managerial Finance by Weston and Brigham (1993). In this book the authors describe four main categories of financial ratios that can be useful when analyzing business performance. The categories include: liquidity ratios, leverage ratios, activity ratios and profitability ratios. Courtis (1978) surveyed several studies in order to identify the variables useful at predicting failure The financial ratios identified were grouped in three main categories: profitability ratios, managerial performance ratios and solvency ratios

The above discussion suggests that financial ratio analysis is a useful method for predicting business performance. However, the fact that the significance of ratios has varied from study to study has promoted the use of a variety of methods for modeling business failures. The different methods have considered both univariate and multivariate analysis techniques. For instance, Beaver (1966) developed an indicator to best differentiate between failed and non-failed firms using univarite analysis techniques. Moreover, Altman (1968) employed multivariate analysis and proved that a discriminant function could be more useful as it considers relationships among variables. In the 1970s, logistic regressions were introduced to financial classification problems. Since then, several other techniques have been employed to assess the same problem, including: recursive-partitioning algorithm (Frydmand et al., 1985); decision support systems (Zopoundis. 1987), expert systems (Srinivasan and Ruparel, 1990), neural networks (Tam, 1991) and data envelopment analysis (Troutt et al. 1996; Emel, 2003).

Another interesting aspect that emerges from the use of ratio analysis is how the ratios will be interpreted. According to Edmister (1972) there are several ways in which ratios can be analyzed to predict small business failure, which include: the ratio's level, the relative level of the borrower's ratio to the average ratio of other small business in the same industry. The purpose of this study is to predict the bankruptcy or to evaluate the performance of 34 public companies listed on the Stock Exchange Equity of WAEMU and on Ghana Stock Exchange after identifying out the techniques and /or variables that are used by banks or financial institutions to predict corporate/SMEs's loans event, or to assess SMEs's credits risks or to predicts their default risk (in the perceptive for banks and 
/or potential investors respectively to deny or to grant loans to these firms or to invest in these companies).

\section{DATA AND METHODOLOGY}

The data set used in this study was the secondary data taken from the web site of the stock exchange of WAEMU (BRVM) www.brvm.org and Ghana Stock exchange (www.gse.com.gh). Out of the 37 companies listed on WAEMU Stock Exchange ${ }^{1}$, we have selected 28 companies excluding all the financial institutions like bank and insurance companies in order to reach efficiently the goal of this study. We have randomly taken only 6 companies from Ghana Stock Exchange excluding financial institutions (banks, insurance companies). Thus, 34 companies sample were arrived at. Then, 2013 financial statements (balance sheets, income statements...) of the chosen companies were taken and after the ratio were calculated in the Excel software. Companies are divided into 7 Sectors ${ }^{2}$ such as Public services, transport, industry, distribution, agriculture, mine, oil and gas). According to the company's size, it has taken account into the market capitalization: firm with market capitalization equal of \$200 millions (large companies), market capitalization higher than $\$ 20$ million and lesser than $\$ 200$ millions (Medium companies) and firm with market capitalization lesser than \$20 millions (Small companies). To perform the results of this study, appropriate and realistic methods have to be used. In this view, multivariate method like Z-Scores of Alman (1968) was used, and so an univariate method like ratios analysis used by many authors (Emel et al. (2003), (Dimitras et al., 1996 was used and finally Principal Component Analysis (PCA ${ }^{3}$ ) was used to determine the principal financial characteristics of the 34 firms. The companies that took part in this study are as following in the table 1

Table 1: List of Companies

\begin{tabular}{|c|l|l|l|l|l|}
\hline $\mathbf{1}$ & ONATEL & $\mathbf{1 3}$ & Movis & $\mathbf{2 5}$ & UNILEVER-CI \\
\hline $\mathbf{2}$ & SERVAIR ABIDJAN & $\mathbf{1 4}$ & CROWN SIEM & $\mathbf{2 6}$ & UNIWAX \\
\hline $\mathbf{3}$ & SICABLE & $\mathbf{1 5}$ & VIVO ENERGY CI & $\mathbf{2 7}$ & SONATEL \\
\hline $\mathbf{4}$ & CFAO-Ci & $\mathbf{1 6}$ & SICOR & $\mathbf{2 8}$ & Enterprise Group Limited \\
\hline $\mathbf{5}$ & CIE & $\mathbf{1 7}$ & AIR LIQUIDE & $\mathbf{2 9}$ & Fan Milk Limited \\
\hline $\mathbf{6}$ & FILTISAC S.A & $\mathbf{1 8}$ & SOLIBRA & $\mathbf{3 0}$ & Golden Star Resources Ltd. \\
\hline $\mathbf{7}$ & NEI-CEDA & $\mathbf{1 9}$ & SMB & $\mathbf{3 1}$ & Ghana Oil Company Limited \\
\hline $\mathbf{8}$ & NESTLE-CI & $\mathbf{2 0}$ & SOGB $-\mathrm{Cl}$ & $\mathbf{3 2}$ & PZ CUSSONS GHANA LTD \\
\hline $\mathbf{9}$ & PALMCI & $\mathbf{2 1}$ & SPHC & $\mathbf{3 3}$ & Tullow Oïl Plc \\
\hline $\mathbf{1 0}$ & PAA & $\mathbf{2 2}$ & SETAO & $\mathbf{3 4}$ & UNIWAX \\
\hline $\mathbf{1 1}$ & SODE-CI & $\mathbf{2 3}$ & SITAB & & \\
\hline $\mathbf{1 2}$ & BOLLORE AFRICA Logistic & $\mathbf{2 4}$ & TOTALCI & & \\
\hline
\end{tabular}

${ }^{1}$ It comprises 8 countries such as Togo, Benin, Ivory Cost, Burkina Faso, Senegal, Guinea Bisseau, Mali, Niger

2 For the7 sectors, agriculture counts 4 companies, industry:15 , distribution: 6; public services:5, transport:2; mine: 1 ; oil and gas: 1

${ }^{3}$ P.Hutchinson, Meric, \& Meric (1998) used Principal Components Analysis (PCA) to identify the financial characteristics of small firms like to achieve quotation on the UK unlisted securities market 


\subsection{Z-Discriminant Analysis (Z- Scores Method)}

The Altman's Z-Score is a statistical tool used to measure the likelihood that a company will go bankrupt. Though Altman devised the Z-Score in the 1960s, the notion of trying to predict which companies would fail was far from known at that time. However, Altman added a statistical technique called multivariate analysis to the mix of traditional ratioanalysis techniques, and this allowed him to consider not only the effects of several ratios on the "predictiveness" of his bankruptcy model, but to consider how those ratios affected each other's usefulness in the model. Altman applied the statistical method of discriminant analysis to a dataset of publicly held manufacturers. The estimation was originally based on data from publicly held manufacturers, but has since been reestimated based on other datasets for private manufacturing, non-manufacturing and service companies. Altman developed the Z-Score after evaluating 66 companies, half of which had filed for bankruptcy between 1946 and 1965. He started out with 22 ratios classified into five categories (liquidity, profitability, leverage, solvency and activity) but eventually narrowed it down to five ratios.

The original discriminant function so-called Z-score formula is defined as followed in table2.

\section{Table 2: Definition of Z-Score Variables}

\begin{tabular}{|c|c|c|}
\hline \multicolumn{3}{|c|}{ Discriminant function: $Z=1.2 X_{1}+1.4 X_{2}+3.3 X_{3}+0.6 X_{4}+0.99 X_{5}$} \\
\hline Variables and ratio & $\begin{array}{l}\text { Coefficient } \\
\text { of the } \\
\text { function }\end{array}$ & Signification \\
\hline $\mathrm{X}_{1}=$ Working Capital / Total Assets & 1.2 & $\begin{array}{l}\text { Measures liquid assets in relation to the size of the } \\
\text { company. }\end{array}$ \\
\hline $\begin{array}{l}\mathrm{X}_{2}=\text { Retained Earnings / Total } \\
\text { Assets }\end{array}$ & 1.4 & $\begin{array}{l}\text { Measures profitability that reflects the company's } \\
\text { age and earning power. }\end{array}$ \\
\hline $\begin{array}{l}\mathrm{X}_{3}=\text { Earnings before Interest and } \\
\text { Taxes / Total Assets }\end{array}$ & 3.3 & $\begin{array}{l}\text { Measures operating efficiency apart from tax and } \\
\text { leveraging factors. It recognizes operating earnings as } \\
\text { being important to long-term viability. }\end{array}$ \\
\hline $\begin{array}{l}\mathrm{X}_{4}=\text { Market Value of Equity / Book } \\
\text { Value of Total Liabilities }\end{array}$ & 0.6 & $\begin{array}{l}\text { Adds market dimension that can show up security } \\
\text { price fluctuation as a possible red flag. }\end{array}$ \\
\hline $\mathrm{x}_{5}=$ Sales $/$ Total Assets & 0.99 & $\begin{array}{l}\text { Standard measure for total asset turnover (varies } \\
\text { greatly from industry to industry).. }\end{array}$ \\
\hline Zones of Discrimination & & Significant \\
\hline Z > 2.99 -"Safe" Zones & & $\begin{array}{l}\text { It means that the company is safe from bankruptcy. It } \\
\text { indicates financial soundness }\end{array}$ \\
\hline $\begin{array}{l}1.81<Z<2.99-\text {-Grey" } \\
\text { Zones }\end{array}$ & & $\begin{array}{l}\text { It means that the company is not totally safe from } \\
\text { bankruptcy, It should pays attention to some } \\
\text { indicators }\end{array}$ \\
\hline $\begin{array}{l}Z<1.81 \text {-"Distress" } \\
\text { Zones }\end{array}$ & & $\begin{array}{l}\text { It means that the company situation is very bad, it } \\
\text { will go on bankruptcy. In other words, it show a high } \\
\text { likelihood of bankruptcy }\end{array}$ \\
\hline
\end{tabular}

Source: Author's compilation 
Thus, the original formula is as following:

Z-Score $=([$ Working Capital $/$ Total Assets $] \times 1.2)+([$ Retained Earnings / Total Assets $] \times$ 1.4) $+([$ Operating Earnings / Total Assets $] \times 3.3)+([$ Market Capitalization / Total Liabilities $] \times 0.6)+([$ Sales/ Total Assets $)] \times 0.99)$

Altman's Z-Score determines how likely a company is to fail. In general, the lower the score, the higher the chance of bankruptcy. The first ratio (working capital / total assets) is a good indicator of a firm's ability to make good on what it owes in the next few months. The second ratio is a good indicator of how in debt the company is and whether it has a history of profitability. The third ratio is a measure of efficiency in that it indicates how many cents the company generates in earnings for every dollar of assets it owns. The fourth ratio is a fluid measure of the market's "confidence" in the company. The fifth ratio is similar to the third ratio in that it measures the company's efficiency in delivering sales from its assets.

\section{EMPIRICAL FINDINGS}

\subsection{Discriminant Analysis (Z- Scores of Altman)}

The Z-score is a linear combination of four or five common business ratios, weighted by coefficients. The coefficients were estimated to identify a set of firms which have to be declared bankruptcy and those which have to be survived, with matching by industry and approximate size (assets). The results of Z -Scores are shown in the the Table 3 .

Table 3: Financial Statements and Z Scores Results

\begin{tabular}{|c|c|c|c|c|c|c|c|}
\hline & \multicolumn{7}{|c|}{2013} \\
\hline $\mathbf{X}_{\mathbf{i}}$ & ONATEL & $\begin{array}{l}\text { SERVAIR } \\
\text { ABIDJAN }\end{array}$ & $\begin{array}{c}\text { BERNABE } \\
-\mathrm{Ci}\end{array}$ & SICABLE & CFAO-Ci & CIE & $\begin{array}{c}\text { FILTISAC } \\
\text { S.A }\end{array}$ \\
\hline $\mathrm{x}_{1}=$ Working capital $/$ Total Assets & 0.0588 & 0.120 & 0.257 & 0.0618 & 0.396 & 0.020 & 0.499 \\
\hline $\begin{array}{c}\mathrm{X}_{2}=\text { Retained Earnings/Total } \\
\text { Assets }\end{array}$ & 0.0981 & -0.059 & 0.00000 & 0.00000 & 0.00006 & 0.00000 & 0.00000 \\
\hline $\begin{array}{c}\mathrm{X}_{3}=\text { Earnings before interest and } \\
\text { tax/Total Assets }\end{array}$ & 0.1464 & 0.298 & 0.105 & 0.157 & 0.118 & 0.018 & 0.018 \\
\hline $\begin{array}{c}\mathrm{X}=\text { Market Value of Equity /Total } \\
\text { Liabilities }\end{array}$ & 0,6212 & 1,352 & 0,933 & 1,194 & 0,974 & 0,046 & 2,511 \\
\hline$P_{5}=$ Sales $/$ Total Assets & 0,0588 & 0,12 & 0,257 & 0,0618 & 0,396 & 0,65 & 0,586 \\
\hline \multicolumn{8}{|c|}{ Z' Score Bankruptcy Model: =1.2. $P_{1}+1.4 . P_{2}+3.3 . P 3+0.6 . P_{4}+0.99 P_{5}$} \\
\hline Z'Score of Altman & 1,65 & 3,71 & 2,47 & 2,5 & 2,93 & 0,75 & 2,75 \\
\hline Dicrimination zone & $\begin{array}{l}\text { Distress } \\
\text { zone }\end{array}$ & Safe zone & $\begin{array}{l}\text { Grey } \\
\text { Zone }\end{array}$ & $\begin{array}{l}\text { Grey } \\
\text { Zone }\end{array}$ & $\begin{array}{l}\text { Grey } \\
\text { Zone }\end{array}$ & $\begin{array}{l}\text { Distress } \\
\text { zone }\end{array}$ & $\begin{array}{l}\text { Grey } \\
\text { Zone }\end{array}$ \\
\hline $\mathbf{X}_{\mathbf{i}}$ & NEI-CEDA & NESTLE-Cl & PALMCI & PAA & SODE-Cl & $\begin{array}{l}\text { BOLLORA } \\
\text { FRICA }\end{array}$ & $\begin{array}{l}\text { CROWN } \\
\text { SIEM }\end{array}$ \\
\hline $\mathrm{x}_{1}=$ Working capital/Total Assets & -0.036 & 0.230 & 1.406 & 0.119 & 0.070 & 0.218 & 1.338 \\
\hline $\mathrm{X}_{2}=$ Retained Earnings/TotalAssets & 0.00196 & -0.12797 & 0.00000 & -0.08131 & 0.00000 & 0.16998 & 0.07714 \\
\hline $\begin{array}{c}\mathrm{X}_{3}=\text { Earnings before interest and } \\
\text { tax/Total Assets(EBIT) }\end{array}$ & 0.018 & 0.053 & 0.113 & 0.099 & 0.021 & 0.075 & 0.032 \\
\hline $\begin{array}{c}\text { X=Market Value of Equity /Total } \\
\text { Liabilities }\end{array}$ & 0.083 & -0.007 & 1.549 & 0.885 & 0.296 & 0.658 & 0.607 \\
\hline $\mathrm{P}_{5}=$ Sales/Total Assets & 0.559 & 1.142 & 0.941 & 0.442 & 0.490 & 0.762 & 1.381 \\
\hline \multicolumn{8}{|c|}{$Z^{\prime}$ Score Bankruptcy Model =1.2. $P_{1}+$ 1.4. $P_{2}+$ 3.3.P3 + 0.6. $P_{4}+0.99 P_{5}$} \\
\hline Z'Score of Altman & 0.70 & 1.40 & 3.92 & 1.32 & 0.81 & 1.90 & 3.55 \\
\hline Dicrimination zone & $\begin{array}{l}\text { Distress } \\
\text { zone }\end{array}$ & $\begin{array}{c}\text { Distress } \\
\text { zone }\end{array}$ & Safe zone & $\begin{array}{l}\text { Distress } \\
\text { zone }\end{array}$ & $\begin{array}{l}\text { Distress } \\
\text { zone }\end{array}$ & Grey zone & $\begin{array}{l}\text { Safe Z } \\
\text { one }\end{array}$ \\
\hline
\end{tabular}


Table 3: Financial Statements and Z Scores Results (continued)

\begin{tabular}{|c|c|c|c|c|c|c|c|}
\hline$x_{i}$ & $\begin{array}{l}\text { VIVO } \\
\text { ENERGY CI }\end{array}$ & SICOR & $\begin{array}{l}\text { AIR } \\
\text { LIQUIDE }\end{array}$ & $\begin{array}{l}\text { SOLIBR } \\
\text { A }\end{array}$ & SMB & SOGB -CI & SPHC \\
\hline $\begin{array}{l}\mathrm{x}_{1}=\text { Working capital/Total } \\
\text { Assets }\end{array}$ & -0.045 & -0.557 & 0.272 & 0.218 & 0.196 & 0.085 & 0.272 \\
\hline $\begin{array}{l}\mathrm{X}_{2}=\text { Retained Earnings/Total } \\
\text { Assets }\end{array}$ & 0.00710 & -0.2269 & -0.0279 & $\begin{array}{l}0.0253 \\
3\end{array}$ & 0.00275 & 0.21111 & 0.31223 \\
\hline $\begin{array}{l}\mathrm{X}_{3}=\text { Earnings before interest } \\
\text { and tax/Total Assets }\end{array}$ & 0.085 & 0.202 & 0.107 & 0.172 & -0.016 & 0.116 & 0.168 \\
\hline $\begin{array}{l}\text { X=Market Value of Equity } \\
\text { /Total Liabilities }\end{array}$ & 0.383 & -0.065 & 0.708 & 0.853 & 0.005 & 1.615 & 2.155 \\
\hline$P_{5}=$ Sales $/$ Total Assets & 3.597 & 0.676 & 0.667 & 1.065 & 0.595 & 0.791 & 1.439 \\
\hline \multicolumn{8}{|c|}{ Z' Score Bankruptcy Model: =1.2. $\mathrm{X}_{1}+1 \cdot 4 \cdot \mathrm{X}_{2}+3 \cdot 3 \cdot \mathrm{X} 3+0.6 \cdot \mathrm{X}_{4}+0.99 \mathrm{X}_{5}$} \\
\hline Z'Score of Altman & 4.03 & 0.31 & 1.73 & 2.43 & 0.78 & 2.53 & 4.04 \\
\hline Dicrimination zone & Safe Zone & $\begin{array}{l}\text { Distress } \\
\text { Zone }\end{array}$ & $\begin{array}{l}\text { Distress } \\
\text { Zone }\end{array}$ & $\begin{array}{l}\text { Grey } \\
\text { Zone }\end{array}$ & $\begin{array}{l}\text { Distress } \\
\text { Zone }\end{array}$ & $\begin{array}{l}\text { Grey } \\
\text { Zone }\end{array}$ & $\begin{array}{l}\text { Safe } \\
\text { Zone }\end{array}$ \\
\hline$x_{i}$ & SETAO & SITAB & MOVIS & TOTALCi & $\begin{array}{l}\text { UNILEVER- } \\
\mathrm{Cl}\end{array}$ & UNIWAX & SONATEL \\
\hline $\begin{array}{l}\mathrm{x}_{1}=\text { Working capital/Total } \\
\text { Assets }\end{array}$ & -1.534 & -0.018 & -0.056 & 0.092 & 0.356 & 0.041 & -0.080 \\
\hline $\begin{array}{l}\mathrm{X}_{2}=\text { Retained Earnings/Total } \\
\text { Assets }\end{array}$ & -8.65796 & 0.02063 & -0.2514 & 0.0000 & -0.0229 & 0.00000 & 0.00000 \\
\hline $\begin{array}{l}\mathrm{X}_{3}=\text { Earnings before interest } \\
\text { and tax/Total Assets }\end{array}$ & 0.051 & 0.164 & -0.082 & 0.135 & -0.013 & 0.063 & 0.263 \\
\hline $\begin{array}{l}\text { X=Market Value of Equity } \\
\text { /Total Liabilities }\end{array}$ & $-0,448$ & 0,433 & 0,038 & 0,673 & 0,272 & 0,55 & 0,621 \\
\hline $\mathrm{P}_{5}=$ Sales $/$ Total Assets & 0,91 & 1,718 & 0,726 & 3,563 & 0,948 & 1,438 & 0,709 \\
\hline
\end{tabular}

Z' Score Bankruptcy Model: =1.2. $\mathrm{X}_{1}+1 \cdot 4 . \mathrm{X}_{2}+3.3 . \mathrm{X3}+0.6 . \mathrm{X}_{4}+0.99 \mathrm{X}_{5}$

\begin{tabular}{|c|c|c|c|c|c|c|c|}
\hline Z'Score of Altman & -13.16 & 2.51 & 0.05 & 4.49 & 1.45 & 2.01 & 1.84 \\
\hline Dicrimination zone & $\begin{array}{l}\text { Distress } \\
\text { Zone }\end{array}$ & $\begin{array}{l}\text { Grey } \\
\text { Zone }\end{array}$ & $\begin{array}{l}\text { Distress } \\
\text { Zone }\end{array}$ & $\begin{array}{l}\text { Safe } \\
\text { Zone }\end{array}$ & $\begin{array}{l}\text { Distress } \\
\text { Zone }\end{array}$ & $\begin{array}{l}\text { Grey } \\
\text { Zone }\end{array}$ & $\begin{array}{l}\text { Grey } \\
\text { Zone } \\
\end{array}$ \\
\hline $\mathbf{x}_{\mathrm{i}}$ & $\begin{array}{l}\text { Enterprise } \\
\text { Group } \\
\text { Limited }\end{array}$ & $\begin{array}{l}\text { Fan Milk } \\
\text { Limited }\end{array}$ & $\begin{array}{l}\text { Golden } \\
\text { Star } \\
\text { Resources } \\
\text { Ltd. }\end{array}$ & $\begin{array}{l}\text { Ghana Oil } \\
\text { Company } \\
\text { Limited }\end{array}$ & $\begin{array}{l}\text { PZ } \\
\text { CUSSONS } \\
\text { GHANA } \\
\text { LTD }\end{array}$ & $\begin{array}{l}\text { Tullow Oil } \\
\text { Plc }\end{array}$ & \\
\hline $\mathrm{x}_{1}=$ Working capital/Total Assets & 0.058 & 0.010 & 0.034 & -0.131 & 0.016 & 0.025 & \\
\hline $\begin{array}{l}\mathrm{X}_{2}=\text { Retained Earnings/Total } \\
\text { Assets }\end{array}$ & 0.00000 & 0.00000 & 0.00000 & 0.00000 & 0.00000 & 0.34624 & \\
\hline $\begin{array}{l}\mathrm{X}_{3}=\text { Earnings before interest } \\
\text { and tax/Total Assets }\end{array}$ & 0.319 & 0.278 & -0.094 & 0.085 & 0.009 & 0.033 & \\
\hline $\begin{array}{l}\mathrm{X}=\text { Market Value of Equity } \\
\text { /Total Liabilities }\end{array}$ & 33.864 & 3.080 & 0.089 & 0.365 & 1.175 & 0.898 & \\
\hline $\mathrm{P}_{5}=$ Sales $/$ Total Assets & 0.387 & 1.373 & 1.436 & 4.878 & 0.087 & 0.230 & \\
\hline \multicolumn{7}{|c|}{ Z' Score Bankruptcy Model: $=1 \cdot 2 \cdot X_{1}+1 \cdot 4 \cdot X_{2}+3 \cdot 3 \cdot X 3+0.6 \cdot X_{4}+0.99 X_{5}$} & \\
\hline Z'Score of Altman & 21.82 & 4.14 & 1.21 & 5.17 & 0.84 & 1.39 & \\
\hline Dicrimination zone & Safe Zone & $\begin{array}{l}\text { Safe } \\
\text { Zone }\end{array}$ & $\begin{array}{l}\text { Distress } \\
\text { Zone }\end{array}$ & Safe Zone & $\begin{array}{l}\text { Distress } \\
\text { Zone }\end{array}$ & $\begin{array}{l}\text { Distress } \\
\text { zone }\end{array}$ & \\
\hline
\end{tabular}

The result in the table 3 shows that out of the 34 companies, 15 companies were on the distress zone (they had the scores lower than 1.81). This means that they have higher chances to go on bankruptcy in the future short time (Shahzad ljaz, Uims-Pmas-Arid, 2013). This indicates that any bank or potential investor cannot have interest in granting loans or investing in those companies. Worst, four of these are in the dangerous or critical 
situation, (one has negative score and the other three have had scores closed to zero). Most of these companies have insufficient working capital which makes it unable for them to finance their current assets leading them to the chronic problem of liquidity. For these reasons, they contracted huge overdrafts on which they were paying high interest rates. Moreover, they were faced with chronic losses on $\mathrm{EBIT}^{4}$ (negative EBIT or low EBIT). Their huge negative Retained earnings have reduced their equities or have led them into negative results. More so, their sales were insufficient; consequently they were not able to cover expenses.

11 of the 34 companies were in the grey zone $(1.81<Z<2.99)$. This indicates that these companies were not safe from bankruptcy. These companies have to pay attention to their working capital, increase their sales and pay attention on contracting to much long term debts. Banks or potential investors must pay or follow with attention these companies if their situation will be improved in short- term time.

Only 8 of the 34 companies were in the safe zone ( $(Z>2.99)$, Shahzad Ijaz, UIMS-PMASArid, 2013).Out of the 8 companies, 3 are listed on the Ghana Stocks Exchanges and the remaining 5 are listed on WAEMU's Stock Exchange (BRMV).

The two first best performing companies were listed on Ghana Stock Exchange. These companies have had the best performances. Thus, Banks or potential investors can accompany them in financing or in investing to sustain their performances.

8 companies (Enterprise Group Limited, Fan Milk Limited, Ghana Oil Company Limited, TOTAL-Ci, SPHC, VIVO ENERGY Cl; CROWN SIEM, SERVAIR ABIDJAN) of the 34 companies' $Z$ Scores indicate that these firms are unlikely to enter bankruptcy; this bodies a good financial position. Banks or investors can respectively finance or invest in their activities without having any serious problem concerning their financial situation. Whereas 15 of them have had worst z- scores. They have a higher probability on going on bankruptcy. Consequently, they cannot inspire the confidence of investors.

\subsection{Financial Ratio Analysis}

The key highlight on financial ratio analysis is to see how financial operations drive value. Some finance analyst refer to this model as the value drivers model that explains how an entity makes to make money and increases its values; others, as the financial lever model which views the financial ratio analysis as the method for identifying the triggers of financial results(Callahan, Stetz, Brooks, 2007). Both of the two schools of thoughts provide information that is needed to analyze the financial information.

A cross -company analysis is used in this study to understand the companies' weaknesses or strengths. The financial ratio formula and interpretation is resume in the Table 4.

\footnotetext{
${ }^{4}$ Earnings Before Interest and Tax
} 


\section{Table 4: Formula of Financial Ratios and Interpretations}

\begin{tabular}{|c|c|c|c|}
\hline Ratio & Formula & Unit & Interpretation \\
\hline Liquidity ratio & \multicolumn{3}{|c|}{$\begin{array}{l}\text { Liquidity ratios are the ratios that measure the ability of a company to meet its short term debt obligations. } \\
\text { These ratios measure the ability of a company to pay off its short-term liabilities when they fall due }\end{array}$} \\
\hline Working Capital ratio & Current Asset/ Current liabilities & Time & $\begin{array}{l}\text { Indicates the ability of the company to pay its short-term } \\
\text { debt. The higher the ratio, the better the financial situation. } \\
\text { This ratio should be greater than } \mathbf{2}\end{array}$ \\
\hline Quick ratio or cash ratio & $\begin{array}{l}\text { Cash }+ \text { Accounts receivable }+ \text { Short- } \\
\text { term Investments) /Current } \\
\text { Liabilities }\end{array}$ & & $\begin{array}{l}\text { Indicates how much the most liquid assets cover current } \\
\text { liabilities } \\
\text { Cash + Accounts receivable + Short-term Investments) } \\
\text { /Current Liabilities. Ideally, this ratio should be greater than } \\
\mathbf{1}\end{array}$ \\
\hline Financial structure Ratio & \multicolumn{3}{|c|}{$\begin{array}{l}\text { Bear witness to the funding of the assets of the company These ratios give indications whether the company } \\
\text { has got enough financial resources to cover its financial obligations when the creditors and lenders seek their } \\
\text { payments }\end{array}$} \\
\hline $\begin{array}{l}\text { Equity-to-long term-debt } \\
\text { Ratio }\end{array}$ & $\begin{array}{l}\text { Shareholders' equity / long-term } \\
\text { debt }\end{array}$ & Time & $\begin{array}{l}\text { Indicates the relationship and equilibrium between funds } \\
\text { Invested by shareholders and those loaned by the bank to } \\
\text { cover the needs of current liquidity A ratio of } 1 \text { means that } \\
\text { the shareholders' equity covers all the long-term-debt }\end{array}$ \\
\hline $\begin{array}{l}\text { Long term Debt to fixed Asset } \\
\text { Ratio }\end{array}$ & long term debt / Fixed assets & Time & $\begin{array}{l}\text { Measures warranty offered in the long term If there are } \\
\text { lease agreements; add them to the long-term debt. The ratio } \\
\text { should be less than } 1\end{array}$ \\
\hline $\begin{array}{l}\text { Coverage of short-term debt } \\
\text { Ratio }\end{array}$ & $\begin{array}{l}\text { (Net profit after tax + Depreciation }+ \\
\text { Interest) / } \\
\text { (Portion of short-term debt }+ \\
\text { interest) }\end{array}$ & & $\begin{array}{l}\text { Measure of the adequacy of the funds generated to repay } \\
\text { long-term debt and interest of the latter } \\
\text { must be greater than } 1\end{array}$ \\
\hline $\begin{array}{l}\text { Short term debt to Asset } \\
\text { Ratio }\end{array}$ & Short term liabilities / Total Assets & $\%$ & $\begin{array}{l}\text { Indicates the portion of total assets financed in the short } \\
\text { term }\end{array}$ \\
\hline $\begin{array}{l}\text { Long-term Debt to assets } \\
\text { Ratio }\end{array}$ & Long term liabilities/Total asset & $\%$ & $\begin{array}{l}\text { Measures the portion of total assets financed in the long } \\
\text { term }\end{array}$ \\
\hline Cash Flow to Asset Ratio & $\begin{array}{l}\text { Shareholders' Equity / Total Assets) } \\
\mathrm{x} 100\end{array}$ & $\%$ & $\begin{array}{l}\text { Measures the portion of total assets financed by } \\
\text { shareholders Must be High }\end{array}$ \\
\hline Management ratios & \multicolumn{3}{|c|}{$\begin{array}{l}\text { Asset management ratios indicate how successfully a company is utilizing its assets to generate revenues. } \\
\text { Analysis of asset management ratios tells how efficiently and effectively a company is using its assets in the } \\
\text { generation of revenues. They indicate the ability of a company to translate its assets into the sales. } \\
\text { Asset management ratios are also known as asset turnover ratios and asset efficiency ratios. }\end{array}$} \\
\hline $\begin{array}{l}\text { Accounts } \\
\text { ReceivableTurnover ratio }\end{array}$ & (Customer Accounts * 365) / Sales & & $\begin{array}{l}\text { Shows the average period elapsing between the time of sale } \\
\text { and the cash is collected from customer }\end{array}$ \\
\hline $\begin{array}{l}\text { Accounts Payable Turnover } \\
\text { Ratio }\end{array}$ & $\begin{array}{l}\text { (Accounts Payable * 365) / Stocks } \\
\text { sold cost }\end{array}$ & Day & $\begin{array}{l}\text { Shows the average period elapsing between the time of } \\
\text { purchase and the payment to the supplier }\end{array}$ \\
\hline $\begin{array}{l}\text { Days Inventory Outstanding } \\
\text { (DIO) }\end{array}$ & Sales /Inventory & Day & $\begin{array}{l}\text { Measure the effectiveness of stock management by } \\
\text { indicating the number of times that stocks are renewed in } 1 \\
\text { year }\end{array}$ \\
\hline Age of inventory & 365/DIO & Day & $\begin{array}{l}\text { Indicates the number of days required to sell } \\
\text { inventory(stocks) }\end{array}$ \\
\hline Annual variation in sales & & $\%$ & $\begin{array}{l}\text { Illustrates the level of sales growth of the company } \\
\text { previous year X100 }\end{array}$ \\
\hline ProfitabilityRatios & \multicolumn{3}{|c|}{$\begin{array}{l}\text { Measure a company's ability to generate earnings relative to sales, assets and equity. These ratios assess the } \\
\text { ability of a company to generate earnings, profits and cash flows relative to relative to some metric, often the } \\
\text { amount of money invested. They highlight how effectively the profitability of a company is being managed }\end{array}$} \\
\hline $\begin{array}{l}\text { Net Earnings ratio } \\
\text { Or Net Profit Margin ratio }\end{array}$ & $\begin{array}{l}\text { (Net profit after taxes / Total Sales) x } \\
100 .\end{array}$ & $\%$ & $\begin{array}{l}\text { Gives an idea of the overall profitability of all operations } \\
\text { of the company; Indicates which net earnings gives off } \\
\text { every dollar of sales. This result can be considered good } \\
\text { or bad according to the standards sectoral applicable to } \\
\text { companies of similar size engaged in similar activities }\end{array}$ \\
\hline $\begin{array}{l}\text { Return on shareholders' } \\
\text { equity or Return On } \\
\text { Equity(ROE) }\end{array}$ & $\begin{array}{l}\text { (Net profit after taxes / Total equity) } \\
x 100 \text {. }\end{array}$ & $\%$ & $\begin{array}{l}\text { Allows assessing the ability of the company to generate } \\
\text { an adequate return to shareholders. Measures the net } \\
\text { profit after tax obtained for every } \$ 100 \text { of equity. }\end{array}$ \\
\hline Return On total assets(ROA) & $\begin{array}{l}\text { assets }=(\text { Net profit after taxes } / \text { Total } \\
\text { Assets) } \times 100\end{array}$ & $\%$ & $\begin{array}{l}\text { Measure the return on investment in business. A } \\
\text { relatively high ratio usually indicates proper operation of } \\
\text { the asset, it must be considered in accordance with } \\
\text { applicable industry standards for companies of similar } \\
\text { size engaged in the same activities. }\end{array}$ \\
\hline
\end{tabular}


Table 5: Findings of Financial Ratios

\begin{tabular}{|c|c|c|c|c|c|c|c|c|c|c|c|c|c|c|c|c|}
\hline \multirow[b]{2}{*}{ Companies } & \multicolumn{2}{|c|}{ Liquidity ratio } & \multicolumn{6}{|c|}{ Financial structure Ratio } & \multicolumn{5}{|c|}{ Management ratio } & \multicolumn{3}{|c|}{ ProfitabilityRatios } \\
\hline & \begin{tabular}{|c}
$\begin{array}{c}\text { Working } \\
\text { capital } \\
\text { Ratio }\end{array}$ \\
\end{tabular} & $\begin{array}{l}\text { Quick } \\
\text { Ratio }\end{array}$ & $\begin{array}{l}\text { Equity-to- } \\
\text { long-term } \\
\text { debt Ratio }\end{array}$ & $\begin{array}{r}\text { term } \\
\text { Debt } \\
\text { fixed- } \\
\text { Assets } \\
\text { ratio } \\
\end{array}$ & $\begin{array}{r}\text { Coverage } \\
\text { of short- } \\
\text { term debt } \\
\text { Ratio } \\
\end{array}$ & $\begin{array}{r}\text { Current } \\
\text { Liability } \\
\text { to asset } \\
\text { ratio } \\
\end{array}$ & $\begin{array}{r}\text { Long- } \\
\text { term } \\
\text { Debt to } \\
\text { assets } \\
\end{array}$ & $\begin{array}{r}\text { Cash flow } \\
\text { to assets } \\
\text { Ratio } \\
\end{array}$ & $\begin{array}{r}\text { Accounts } \\
\text { Receivable } \\
\text { Turnover } \\
\text { ratio } \\
\end{array}$ & $\begin{array}{r}\text { Account } \\
5 \\
\text { Payable } \\
\text { Turnove } \\
r \text { Ratio } \\
\end{array}$ & DIO & $\begin{array}{r}\text { Age of } \\
\text { inventor } \\
y \\
\end{array}$ & $\begin{array}{r}\text { Annual } \\
\text { variatio } \\
n \text { in } \\
\text { sales } \\
\end{array}$ & \begin{tabular}{|r} 
Net \\
Earnings \\
\end{tabular} & ROA & ROE \\
\hline ONATEL & 1.120 & 0.987 & 5.01 & 0.21 & 0.58 & $46.70 \%$ & $14.98 \%$ & $38.32 \%$ & 42.51 & 312.57 & 28.14 & 12.97 & $6.02 \%$ & $16.59 \%$ & $25.59 \%$ & $9.81 \%$ \\
\hline SERVAIR ABIDJAN & 2.03 & 1.74 & 6.15 & 0.29 & 0.78 & $32.68 \%$ & $9.34 \%$ & $57.48 \%$ & 39.1564 & 145.81 & 17.57 & 20.78 & $-3.61 \%$ & $10.90 \%$ & $35.60 \%$ & $20.46 \%$ \\
\hline BERNABE $-\mathrm{Ci}$ & 1.53 & 1.53 & 11.34 & 0.213 & 0.238 & $41.51 \%$ & $3.72 \%$ & $42.19 \%$ & 49.90 & 172.05 & 2.54 & 143.77 & $25.50 \%$ & $5.70 \%$ & $17.11 \%$ & $7.22 \%$ \\
\hline SICABLE & 2.819 & 2.297 & 4.630 & 0.238 & 0.180 & $33.82 \%$ & $11.76 \%$ & $54.43 \%$ & 67.88 & 183.48 & 6.80 & 53.67 & $-3.75 \%$ & $9.81 \%$ & $21.65 \%$ & $11.78 \%$ \\
\hline CFAO-Ci & $\overline{1.45}$ & 0.83 & 1.45 & 0.132 & 0.383 & $46.3 \%$ & $4.31 \%$ & $49.35 \%$ & $49.35 \%$ & 0.383 & 5.23 & 69.81 & $25.50 \%$ & $5.35 \%$ & $16.28 \%$ & $8.03 \%$ \\
\hline CIE & 1.04 & 0.9980 & 0.833 & 0.657 & 0.038 & $88.49 \%$ & $5.26 \%$ & $4.38 \%$ & 489.25 & 643.64 & 19.70 & 18.53 & $14.79 \%$ & $2.22 \%$ & $33.00 \%$ & $1.45 \%$ \\
\hline FILTISAC S.A & 2.06 & 1.30 & 5.276 & & 0.711 & $30.91 \%$ & $11.01 \%$ & $58.08 \%$ & 0.240 & 127.83 & 2.50 & 146.20 & $8.34 \%$ & $6.12 \%$ & $6.18 \%$ & $3.59 \%$ \\
\hline NEI-CEDA & 2.06 & 0.881 & 3.266 & 0.325 & 0.032 & $90.04 \%$ & $2.33 \%$ & $7.62 \%$ & 493.50 & 1280.78 & 3.08 & 118.62 & $5 \%$ & $0.86 \%$ & $6.34 \%$ & $0.48 \%$ \\
\hline NESTLE-Cl & 1.083 & 1.52 & -0.012 & 1.418 & 0.322 & $65.22 \%$ & $35.20 \%$ & $-0.42 \%$ & 108.78 & 1403.25 & 7.92 & 46.09 & $1.40 \%$ & $0.51 \%$ & $-137.9 \%$ & $0.59 \%$ \\
\hline PALMCI & 1.59 & 0.91 & 3.043 & 0.298 & 1.166 & $19.71 \%$ & $19.84 \%$ & $60.43 \%$ & 55.36 & 131.66 & 7.05 & 51.80 & $-14.0 \%$ & $8.40 \%$ & $13.09 \%$ & $7.91 \%$ \\
\hline PAA & 2.94 & 2.92 & 1.38 & 0.77 & 0.94 & $19.03 \%$ & $34.02 \%$ & $46.96 \%$ & 95.41 & 807.25 & 103.32 & 3.53 & $14.00 \%$ & $21.25 \%$ & $20.03 \%$ & $9.40 \%$ \\
\hline SODE-CI & 1.15 & 1.09 & 0.297 & 1.242 & 0.069 & $75.36 \%$ & $16.54 \%$ & $4.91 \%$ & 533.66 & 1874.80 & 10.99 & 33.20 & $17.58 \%$ & $3.19 \%$ & $31.79 \%$ & $1.56 \%$ \\
\hline BOLLORE AFRICA Logistic & 1.38 & 1.36 & 4.70 & 0.31 & 0.32 & $53.54 \%$ & $8.15 \%$ & $38.31 \%$ & 338.370 & 1964.14 & 69.4 & 5.26 & $1.58 \%$ & $13.04 \%$ & $25.95 \%$ & $9.94 \%$ \\
\hline CROWN SIEM & 1.77 & 1.03 & 3.10 & 1.05 & 0.14 & $16.91 \%$ & $12.16 \%$ & $37.76 \%$ & 101.91 & 139.04 & 3.77 & 96.86 & $0.10 \%$ & $0.57 \%$ & $2.09 \%$ & $0.79 \%$ \\
\hline VIVO ENERGY CI & 0.83 & 0.69 & 1.43 & 0.34 & 0.22 & $53.00 \%$ & $19.31 \%$ & $27.69 \%$ & 32.737 & 50.164 & 50.846 & 7.178 & $42.21 \%$ & $1.42 \%$ & $18.39 \%$ & $5.09 \%$ \\
\hline SICOR & 0.83 & 0.34 & -0.376 & 0.263 & 0.236 & $88.50 \%$ & $18.42 \%$ & $-6.92 \%$ & 160.65 & 859.44 & 1195.63 & 0.31 & $145.2 \%$ & $3.4 \%$ & $-33.2 \%$ & $2.3 \%$ \\
\hline AIR LIQUIDE & 0.83 & 1.25 & 4.982 & 0.520 & 0.343 & $50.24 \%$ & $8.32 \%$ & $41.44 \%$ & 201.73 & 447.16 & 3.16 & 115.34 & $17.44 \%$ & $11.84 \%$ & $19.05 \%$ & $7.89 \%$ \\
\hline SOLIBRA & 1.10 & 0.24 & 3.282 & 0.251 & 1.170 & $39.92 \%$ & $14.03 \%$ & $46.05 \%$ & 14.54 & 55.31 & 3.07 & 118.74 & $7.88 \%$ & $11.69 \%$ & $27.03 \%$ & $12.45 \%$ \\
\hline$S M B$ & 1.02 & 0.90 & 3.282 & 1.197 & 0.044 & $90.39 \%$ & $9.09 \%$ & $0.53 \%$ & 473.15 & 603.11 & 5.30 & 68.86 & $-44.29 \%$ & $-3.4 \%$ & $-639.3 \%$ & $-3.4 \%$ \\
\hline SOGB -Cl & 1.046 & 0.537 & 5.37 & 0.16 & 0.94 & $26.73 \%$ & $11.50 \%$ & $61.76 \%$ & 56.52 & 61.20 & 5.81 & 62.83 & $11.47 \%$ & $8.84 \%$ & $11.32 \%$ & $6.99 \%$ \\
\hline SPHC & 1.49 & 0.638 & 200.92 & 0.01 & 1.10 & $31.35 \%$ & $0.24 \%$ & $68.31 \%$ & 94.81 & 87.48 & 5.40 & 67.58 & $-10.03 \%$ & $8.81 \%$ & $18.56 \%$ & $12.45 \%$ \\
\hline SETAO & 0.523 & 0.522 & -26.02 & 0.46 & 0.03 & $178.1 \%$ & $3.1 \%$ & $-81.2 \%$ & 99.05 & 821.08 & 461.44 & 0.79 & $567.5 \%$ & $5.87 \%$ & $-6.57 \%$ & $5.34 \%$ \\
\hline SITAB & 1.226 & 0.416 & 10.55 & 0.16 & 0.27 & $66.9 \%$ & $2.9 \%$ & $30.2 \%$ & 4.22 & 201.21 & 3.17 & 115.09 & 0 & $1.6 \%$ & $9.4 \%$ & $2.8 \%$ \\
\hline MOVIS & 0.530 & 0.519 & 0.30 & 0.22 & 0.02 & $47.06 \%$ & $12.25 \%$ & $3.70 \%$ & 203.73 & 1617.41 & 76.13 & 4.79 & $-3.04 \%$ & $-12.98 \%$ & $-254.2 \%$ & $-9.42 \%$ \\
\hline TOTALCi & 1.13 & 0.85 & 10.32 & 0.11 & 0.29 & $55.88 \%$ & $3.90 \%$ & $40.22 \%$ & 40.63 & 39.17 & 22.21 & 16.43 & $23.65 \%$ & $2.72 \%$ & $24.07 \%$ & $9.68 \%$ \\
\hline UNILEVER-CI & 0.525 & 0.376 & 2.07 & 0.10 & 0.09 & $83.25 \%$ & $5.46 \%$ & $11.29 \%$ & 107.2 & 296.2 & 7.7 & 47.577 & $-19.60 \%$ & $-3.6 \%$ & $-30.1 \%$ & $-3.4 \%$ \\
\hline UNIWAX & 1.14 & 0.44 & 6.48 & 0.17 & 0.19 & $59.1 \%$ & $5.5 \%$ & $35.5 \%$ & 56.06 & 214.63 & 5.73 & 104.285 & $5.47 \%$ & $4.15 \%$ & $16.83 \%$ & $5.97 \%$ \\
\hline SONATEL & 1.11 & 1.06 & 0.92 & 0.44 & 0.63 & $35.7 \%$ & $64.3 \%$ & $58.9 \%$ & 9.50 & 1099.57 & 5.73 & 63.675 & $11.41 \%$ & $25.68 \%$ & $30.91 \%$ & $18.21 \%$ \\
\hline Enterprise Group Limited & 8.281 & 3.014 & 33.864 & 0.06 & 11.187 & $2.9 \%$ & $3.38 \%$ & $97.1 \%$ & 0 & 0 & 0 & 0.000 & $57.17 \%$ & $82.9 \%$ & $33.0 \%$ & $32.1 \%$ \\
\hline Fan Milk Limited & 1.966 & 1.152 & 15.274 & 0.080 & 2.941 & $2.0 \%$ & $4.94 \%$ & $75.49 \%$ & 42.3 & 44.9 & 8.6 & 42.3 & $-5.60 \%$ & $15.6 \%$ & $28.4 \%$ & $21.5 \%$ \\
\hline Golden Star Resources Ltd. & 1.082 & 0.588 & 0.320 & 0.470 & 0.627 & $42.10 \%$ & $25.60 \%$ & $8.20 \%$ & 52.8 & 456.3 & 6.9 & 52.8 & $-15.03 \%$ & $-63.81 \%$ & $-1117 . \%$ & $-91.64 \%$ \\
\hline Ghana Oil Company Limited & 0.914 & 0.802 & 9.037 & 0.079 & 0.127 & $68.69 \%$ & $2.96 \%$ & $26.73 \%$ & 32.5 & 56.0 & 63.4 & 5.8 & $25.89 \%$ & $1.54 \%$ & $28.11 \%$ & $7.51 \%$ \\
\hline PZ CUSSONS GHANA LTD & 1.541 & 0.974 & 3.252 & 0.303 & 0.267 & $2.94 \%$ & $1.66 \%$ & $5.40 \%$ & 72.9 & 87.8 & 5.2 & 69.6 & $2.90 \%$ & $8.04 \%$ & $13.00 \%$ & $0.70 \%$ \\
\hline Tullow Oil Plc & 1.445 & 1.309 & 1.176 & 0.490 & 0.274 & $12.45 \%$ & $40.23 \%$ & $47.32 \%$ & 42.6 & 315.0 & 13.7 & 26.7 & $12.92 \%$ & $8.17 \%$ & $3.97 \%$ & $1.88 \%$ \\
\hline
\end{tabular}

Source: Author's calculations 


\subsubsection{Interpretation of Findings}

The findings provided in the Table 5 are interpreted in the Table 6 as following:

Table 6: Interpretation of Results

\begin{tabular}{|c|c|}
\hline Ratio & Findings \\
\hline $\begin{array}{l}\text { Liquidity } \\
\text { Ratio }\end{array}$ & $\begin{array}{l}\text { Liquidity ratios are insufficient for all the companies except } 7 \text { companies (Fan Milk Limited, } \\
\text { SERVAIR ABIDJAN ,Port Autonome of Abidjan (PAA), FILTISAC S.A, NEI-CEDA, SICABLE, } \\
\text { Enterprise Group Limited) which did not suffer from liquidity (for both Quick ratio and } \\
\text { working capital ratio) problems. The theoretical result of immediate cash (quick ratio) is at } \\
\text { least } 1 \text { (only } 13 \text { companies have reached it), for the working capital ratio, it must be at least } 2 \text {. } \\
\text { The firms which did not reach these ratios meant that they did not meet their current } \\
\text { obligations. This situation can cause serious cash flow problems. It is strongly recommended } \\
\text { to strengthen the sales function. }\end{array}$ \\
\hline $\begin{array}{l}\text { Financial } \\
\text { structure } \\
\text { ratios }\end{array}$ & $\begin{array}{l}\text { Equity to long-term debt ratio was in average good for all the companies except } 7 \text { companies } \\
\text { (Golden Star Resources Ltd (0.32). SONATEL (0.92, SETAO (-26.02), MOVIS (-0.30), SICOR (- } \\
\text { 376), SODE-CI (0.296), NESTLE-CI (-0.012) that have ratios near to zero for } 3 \text { companies and } \\
\text { higher negative ratio for the four others. Indeed for those that got higher negative ratios, } \\
\text { their retained earnings and yearly net profit margin were highly negative; and for others, } \\
\text { their equity were insufficient to cover their total Long-term debt or they had contracted a } \\
\text { huge amount of debt than they should. This indicates that these companies are not showing } \\
\text { comfortable financial situations.The theory for ratio says that it must be at least one } 1 . \\
\text { Concerning Long-term Debt to Fixed Asset Ratio, the results were quite good in average for } \\
\text { all the companies except four companies such as SMB. CROWN SIEM, SODE-CI, NESTLE-CI } \\
\text { which have had ratios higher than } 1 \text {. This means that their indebtedness is too high. It shows } \\
\text { that their fixed assets are totally and solely funded by long-term debts while fixed assets } \\
\text { should be financed by a portion of the equity. This can be explained by the strong anterior } \\
\text { accumulated losses retained earnings that have engulfed the equity. These companies need } \\
\text { to raise a new equity or to increase their sales. } \\
\text { Short-term debt financing ratio: the coverage of short-term debt by earnings before interest, } \\
\text { tax, depreciation and amortization (EBITDA) is not sufficient for all the companies except five } \\
\text { companies (Fan Milk Limited, Enterprise Group Limited, SPHC; SOLIBRA, PALMCI) that have } \\
\text { had satisfactory results. Their EBITDA have largely covered their current liabilities (short-term } \\
\text { debts.). As the theory suggests a level of } 1 \text {, the results of } 29 \text { other companies were below the } \\
\text { minimum required ratio. The effort must be made to better focus proportions at this level. } \\
\text { Financing Assets ratio: there is no limit or ceiling required for ratios of Short- term liabilities } \\
\text { to assets, Long-term liabilities funding of the assets and Cash Flow to Assets. However, the } \\
\text { results must be the best possible. Regarding these ratios, it is to judge the proportion of Short } \\
\text {-term and long term debts to assets. Both debts should not cover more than } 60 \% \text { of assets. }\end{array}$ \\
\hline $\begin{array}{l}\text { Management } \\
\text { ratios }\end{array}$ & $\begin{array}{l}\text { Accounts receives turnover ratio when compared to the payable turnover ratio, must be } \\
\text { lesser than the payables ratio and the period of clients' payment should not at most } \\
\text { theoretically exceed } 90 \text { days. This is, in order, to avoid treasury or cash problems. The results } \\
\text { from table } 5 \text { show that few companies have satisfied these conditions. For most of } \\
\text { companies; their accounts receives turnover ratios were higher than the payables turnover } \\
\text { ratios. This means they used to pay their suppliers earlier than their customers used to pay } \\
\text { them. This situation is not comfortable for them and they were faced with major problem of } \\
\text { treasury or immediate cash problem which led them to contract bank overdraft debts which } \\
\text { were very expensive in terms of interest rate. Moreover, for some of these companies, their } \\
\text { accounts receives period are over than } 6 \text { to } 9 \text { months. This situation is not acceptable for } \\
\text { them. } \\
\text { Concerning the inventory turnover or Days Inventory Outstanding (DIO) ratio, bigger is this } \\
\text { ratio best will be the company's sales situation, and least will be the age of inventory in the } \\
\text { company. } \\
\text { Regarding to annual variation of sales, the table } 5 \text { shows that out of } 34 \text { companies } 9 \\
\text { companies had a negative variation of sales in the year } 2013 \text { compared to } 2012 \text {. This variation }\end{array}$ \\
\hline
\end{tabular}




\begin{tabular}{|c|c|}
\hline & $\begin{array}{l}\text { was from -3.04\% to }-44.26 \% \text {. This decrease in sales had led some of them to big profit losses. } \\
\text { Globally, few companies have satisfactory results in this ratio except companies in services } \\
\text { sector which are not dealt with inventory. Concerning the management ratios, companies } \\
\text { which have had satisfactory results were Ghana Oil Company Limited, Fan Milk Limited, } \\
\text { Tullow Oil PIc, VIVO ENERGY CI, PAA, SERVAIR ABIDJAN. This situation reinforces their } \\
\text { immediate cash flow and working capital's good situation. } \\
\text { For companies that were in bad situation, arbitration between the holding period of } \\
\text { inventory and inventory turnover should be done to minimize the costs of procurement and } \\
\text { holding these inventories. The low level of inventory gives priority to cost minimization for } \\
\text { placing orders, the cost of ownership is minimal. The level of annual sales growth should be } \\
\text { perpetually provided in addition to generate increasing profits. In general, sales must evolve } \\
\text { faster than expenses }\end{array}$ \\
\hline $\begin{array}{l}\text { Profitability } \\
\text { ratios }\end{array}$ & $\begin{array}{l}\text { Regarding to profitability ratios, there were a few companies that have higher levels of } \\
\text { profitability in the three ratios following: Net Margin, Return on Equity (ROE) and Return on } \\
\text { Assets (ROA).These companies were Fan Milk Limited. Enterprise Group Limited. SONATEL, } \\
\text { SOLIBRA, AIR LIQUIDE. PAA, SICABLE, and ONATEL, SERVAIR ABIDJAN. Among these, } \\
\text { Enterprise Group Limited had the highest level in the three ratios (Net margin ratio: 82\%; } \\
\text { ROE: 33\%; ROA: 32\%). } \\
\text { Moreover, all the remaining companies have low levels of profitability but some of them } \\
\text { according to their sector are quiet acceptable except four companies such as Golden Star } \\
\text { Resources Ltd... UNILEVER-CI,. MOVIS, SMB which had the worst results in the three ratios. } \\
\text { In other words, their results were negative leading their companies and their shareholders } \\
\text { into a very critical financial situation. } \\
\text { These companies and the ones that had low level in profitability should change their present } \\
\text { strategies in the future by increasing their sales, increasing their equity, minimizing their } \\
\text { overheads, ensuring good management of their bottom balance sheet (inventory, receives } \\
\text { and payable accounts) in order to ensure in the future an acceptable and permanent increase } \\
\text { of profits. } \\
\text { In the light of these results (ratio analysis), it is noted that out of the } 34 \text { companies, } \\
\text { objectively } 8 \text { companies (Enterprise Group Limited. Fan Milk Limited. Ghana Oil Company } \\
\text { Limited. TOTALCi, SPHC, VIVO ENERGY Cl; CROWN SIEM. PALMCI, SERVAIR ABIDJAN) had } \\
\text { the best performance results. Basing on this performance, these companies are not likely to } \\
\text { go on bankruptcy. Thus, Banks and /or Potential investors should not hesitate to accompany } \\
\text { them in their respective activities. } \\
\text { For the following } 11 \text { companies (BOLLORE AFRICA L. FILTISAC S.A. CFAO-Ci, SICABLE. } \\
\text { BERNABE Ci. SOGB.CI, SOLIBRA, SONATEL, SITAB, and UNIWAX), their performance } \\
\text { situations were acceptable but are not stable and need some efforts to stabilize their } \\
\text { situation. While for the remaining } 15 \text { companies, their performance situations were critical. If } \\
\text { they do not do anything quickly to solve this situation, they will go automatically on } \\
\text { bankruptcy. }\end{array}$ \\
\hline
\end{tabular}

\subsection{Principal Component Analysis (PCA) Method}

Principal Component Analysis (PCA) is a statistical procedure that uses an orthogonal transformation to convert a set of observations of possibly correlated variables into a set of values of linearly uncorrelated variables called principal components. The number of principal components is less than or equal to the number of original variables. This transformation is defined in such a way that the first principal component has the largest possible variance (that is accounts for as much of the variability in the data as possible) and each succeeding component in turn has the highest variance possible under the constraint that it is orthogonal to (i.e.. uncorrelated with) the preceding components. The principal components are orthogonal because they are the eigenvectors of the covariance 
matrix which is symmetric. PCA is sensitive to the relative scaling of the original variables. The definition of variables is found in Table 7 as follows.

Table 7: Definition of Variables

\begin{tabular}{|l|l|c|}
\hline \multicolumn{1}{|c|}{ Variable } & Definition of Ratios & U \\
\hline R1 & Inventory's Age & Days \\
\hline R2 & Cash flow to Asset Ratio & $\%$ \\
\hline R3 & Net Margin Ratio & Times \\
\hline R4 & Coverage of short-term debt & Times \\
\hline R5 & Equity to Long term Debt ratio & $\%$ \\
\hline R6 & Current Liabilities to asset ratio & $\%$ \\
\hline R7 & Long-term Debt to assets ratio & Times \\
\hline R8 & Long-term Debt to Fixed Asset Ratio & Times \\
\hline R9 & Working capital ratio & Times \\
\hline R10 & Quick ratio or cash ratio & Days \\
\hline R11 & Account Receivable turnover Ratio & Days \\
\hline R12 & Payable turnover Ratio & $\%$ \\
\hline R13 & Return On total assets(ROA) & $\%$ \\
\hline R14 & Return On Equity(ROE) & Times \\
\hline R15 & Inventory Turnover & $\%$ \\
\hline R16 & Annual changes in sales & \\
\hline
\end{tabular}

The results of the PCA method is presented in figure1

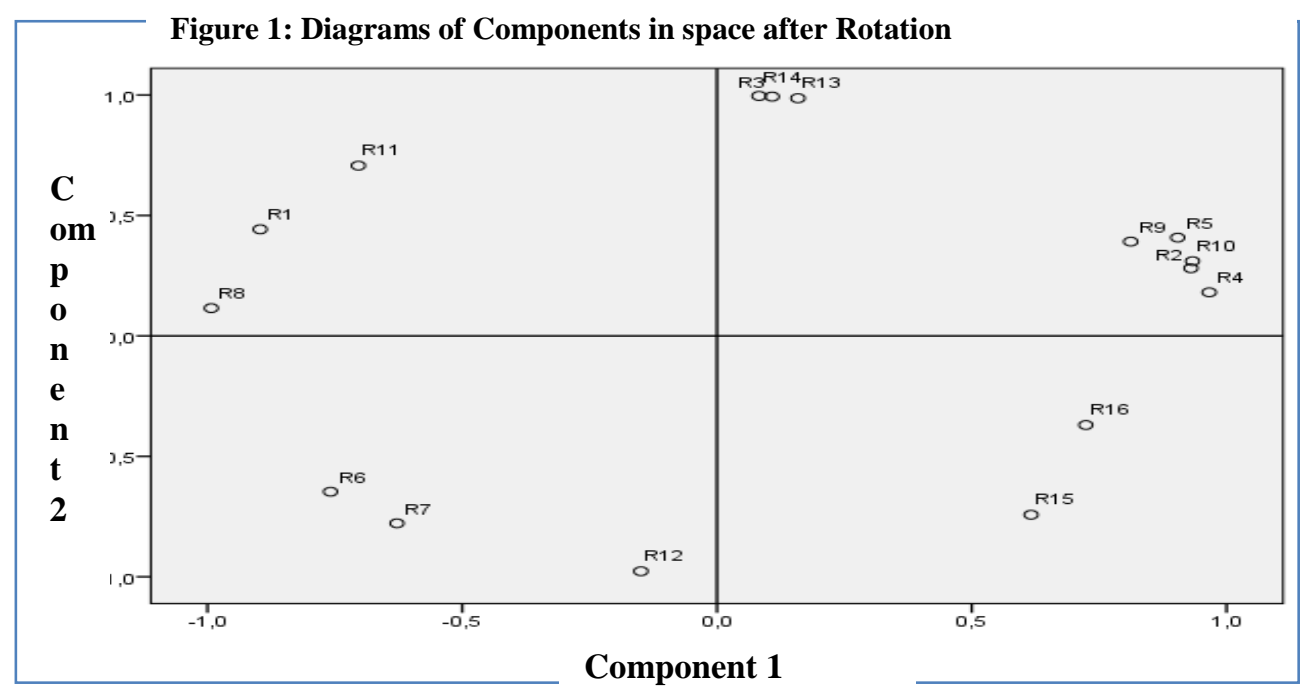

Source SPSS: 20.PCA:

The Figure 1 shows that the projected variables are within the circle of correlation. Most one variable is projected into the circle, the better it is represented. If two well represented variables are closed to each other, it means that they are positively correlated but conversely they are negatively correlated. Thus, R3, R13 and R14 are well represented and positively correlated and closed to each other. 
In financial orthodoxy, Return on total assets (R14) and Return on shareholders' equity (R13) depend and are bounded to Net margin. The more the net margin, the higher the R13 and R14 and happier will be the shareholders.

We can also see that Cash Flows to Asset Ratio (R2), Coverage of short-term debt (R4), Equity to Long-term debt Ratio (R5), Working Capital Ratio (R9), and Quick Ratio or Cash Ratio (R10) are strongly and positively correlated and are closed to each other. These ratios are classified in the first component and were financial structure ratios except Quick ratio. These ratios are important points on which financial institutions or banks put their attention before granting loans.

More so, R15 and R16 are positively correlated but are not close to each other but loaded in the first component. These two ratios are management ratio.

Current Liabilities to asset ratio (R6), Long-term Debt to assets ratio (R7) and Accounts Payable Ratio (R12) are not closed to each other and are negatively correlated whereas ratios R1 (Inventory Age)., .R8 (Long-term Debt to Fixed Asset Ratio) and R11 (Accounts Receivable Ratio) are well represented and positively loaded in the second component but had not been closed to each other.

When based on Principal Component Analysis, eight ratios such as R3, R13 and R14 in one side, and R2, R4, R5, R9 and R10 in other side are strongly and positively correlated and closed to each other. More, they are loaded in the first component. Shortly, in term of company's performance credit risk, default risk assessment, banks and/ or financial institutions used to take a particular attention on these ratios.

In the table 8 , the analysis of bankruptcy or the default risk of the 34 companies through these ratios show results as followings:

Concerning Coverage of Short-term debt, only 5 companies have exceeded the theoretical standard which must be at least 1 . This indicates that these companies have generated sufficient funds to cover their short term debt. Efforts should be made by the remaining 29 companies to reach this standard in the future.

Concerning Equity to Long term-debt (Bank) ratio, all the companies have good performances that were above of the minimum standard ratio 1 except 7 companies which did not reach this standard ratio. Also, 8 companies got the best performance results in this ratio.

Concerning Working capital ratio and Quick or cash ratio respectively 27 and 21 companies have had the poor performance without reaching the minimum standard of 2 and 1 . Among the 13 companies that have reached the minimum standard of 1 for Quick ratio, 8 (Enterprise Group Limited, Fan Milk Limited, Ghana Oil Company Limited. TOTAL.Ci. SPHC, VIVO ENERGY CI; CROWN SIEM, PALMCI, SERVAIR ABIDJAN) of them have had the best performances. This indicates that these companies do not have any problem of liquidity.

When based on Return On Total Assets, Return On shareholders' Equity and Net Margin Ratios, only 8 companies (Fan Milk Limited, Enterprise Group Limited, SONATEL, SOLIBRA, AIR LIQUIDE, PAA, SICABLE, and ONATEL SERVAIR ABIDJAN.). Apart from four companies that are likely to go on bankruptcy because of their worst financial performances, the remaining 22 companies have low performance results which can be acceptable due to their sectors. 
Table 8: Financial Ratio Analysis based on Principal Component Analysis

\begin{tabular}{|c|c|c|c|c|c|c|c|c|c|c|c|c|c|c|c|c|c|}
\hline & ONATEL & $\begin{array}{l}\text { SERVAIR } \\
\text { ABIDJAN } \\
\end{array}$ & $\begin{array}{l}\text { BERNAB } \\
\mathrm{E}-\mathrm{Ci}\end{array}$ & SICABLE & CFAO-Ci & $\mathrm{CIE}$ & FILTISAC S.A & NEI-CEDA & NESTLE-CI & PALMCI & PAA & SODE-CI & $\begin{array}{l}\text { BOLLOREE } \\
\text { AFRICA } \\
\text { Logistic } \\
\end{array}$ & $\begin{array}{l}\text { CROWN } \\
\text { SIEM }\end{array}$ & $\begin{array}{l}\text { VIVO } \\
\text { ENERGY } \\
\mathrm{CI} \\
\end{array}$ & SICOR & Unit \\
\hline & & & 42.19 & & & & & & & & & & & 37.76 & & & $\%$ \\
\hline Cash flow to Fixed Asset(R2) & $38.32 \%$ & $57.48 \%$ & $\%$ & $54.4 \%$ & $49.35 \%$ & $4.38 \%$ & $58.08 \%$ & $7.62 \%$ & $-0.42 \%$ & $60.43 \%$ & $46.96 \%$ & $4.91 \%$ & $38.31 \%$ & $\%$ & $27.69 \%$ & $-6.92 \%$ & \\
\hline Net Profit Margin (R3) & $16.59 \%$ & $10.90 \%$ & $5.70 \%$ & $9.81 \%$ & $5.35 \%$ & $2.22 \%$ & $6.12 \%$ & $0.86 \%$ & $0.51 \%$ & $8.40 \%$ & $21.25 \%$ & $3.19 \%$ & $13.04 \%$ & $0.57 \%$ & $1.42 \%$ & $3.40 \%$ & $\%$ \\
\hline Coverage of short-term debt( R4) & 0.58 & 0.78 & 0.238 & 0.18 & 0.383 & 0.038 & 0.711 & 0.032 & 0.322 & 1.166 & 0.94 & 0.069 & 0.32 & 0.14 & 0.22 & 0.236 & Time \\
\hline Equity to Long term Debt Ratio( R5) & 5.01 & 6.15 & 11.34 & 4.63 & 11.45 & 0.833 & 5.276 & 3.266 & -0.012 & 3.043 & 1.38 & 0.297 & 4.7 & 3.1 & 1.43 & -0.376 & Time \\
\hline Working capital ratio(R9) & 1.12 & 2.03 & 1.53 & 2.819 & 1.45 & 1.04 & 2.06 & 1.083 & 1.9 & 1.59 & 2.942 & 1.15 & 1.38 & 1.77 & 0.83 & 0.34 & Time \\
\hline Quick ratio or cash ratio (R10) & 0.987 & 1.74 & 0.6 & 2.297 & 0.83 & 0.998 & 1.3 & 0.881 & 1.52 & 0.91 & 2.919 & 1.09 & 1.36 & 1.03 & 0.69 & 0.34 & Time \\
\hline Return on shareholders' equity & & & 17.11 & & & & & & & & & & & & & & $\%$ \\
\hline (R13) & $25.59 \%$ & $35.60 \%$ & $\%$ & $21.65 \%$ & $16.28 \%$ & $33.00 \%$ & $6.18 \%$ & $6.34 \%$ & $-137.9 \%$ & $13.09 \%$ & $20.03 \%$ & $31.79 \%$ & $25.95 \%$ & $2.09 \%$ & $18.39 \%$ & $-33.20 \%$ & \\
\hline Return on total assets( R14) & $9.81 \%$ & $20.46 \%$ & $7.22 \%$ & $11.78 \%$ & $8.03 \%$ & $1.45 \%$ & $3.59 \%$ & $0.48 \%$ & $0.59 \%$ & $7.91 \%$ & $9.40 \%$ & $1.56 \%$ & $9.94 \%$ & $0.79 \%$ & $5.09 \%$ & $2.30 \%$ & $\%$ \\
\hline
\end{tabular}

\begin{tabular}{|c|c|c|c|c|c|c|c|c|c|c|c|c|c|c|c|c|c|}
\hline & SMB & $\begin{array}{l}\text { SOGB } \\
\mathrm{Cl}\end{array}$ & SPHC & SETAO & SITAB & MOVIS & TOTAL & UNILEVER-CI & UNIWAX & SONATEL & $\begin{array}{l}\text { Enterprise } \\
\text { Group } \\
\text { Limited }\end{array}$ & $\begin{array}{l}\text { Fan Milk } \\
\text { Limited }\end{array}$ & $\begin{array}{l}\text { Golden } \\
\text { Star } \\
\text { Resources } \\
\text { Ltd. }\end{array}$ & $\begin{array}{l}\text { Ghana Oil } \\
\text { Company } \\
\text { Limited }\end{array}$ & $\begin{array}{l}\text { PZ } \\
\text { CUSSONS } \\
\text { GHANA } \\
\text { LTD }\end{array}$ & $\begin{array}{l}\text { Tullow } \\
\text { Oil Plc }\end{array}$ & Unit \\
\hline Cash flow to Fixed Asset(R2) & 603.11 & 61.2 & 87.48 & 821.08 & 201.21 & 1617 & 39.17 & 296.2 & 214.63 & 1099.57 & & 44.9 & 456.3 & 56 & 87.8 & 315 & $\%$ \\
\hline Net Profit Margin(R3) & $-3.40 \%$ & $6.99 \%$ & $12.68 \%$ & 0.0534 & $2.80 \%$ & $-9.42 \%$ & $9.68 \%$ & $-3.40 \%$ & $5.97 \%$ & $18.21 \%$ & $32.10 \%$ & $21.50 \%$ & $-91.64 \%$ & $7.51 \%$ & $0.70 \%$ & $1.88 \%$ & $\%$ \\
\hline Coverage of short-term debt(R4) & $9.09 \%$ & $11.50 \%$ & $0.24 \%$ & $3.10 \%$ & $2.90 \%$ & $12.25 \%$ & $3.90 \%$ & $5.46 \%$ & $5.50 \%$ & $64.30 \%$ & $3386.40 \%$ & $4.94 \%$ & $25.60 \%$ & $2.96 \%$ & $1.66 \%$ & $40.23 \%$ & Time \\
\hline Equity to Long term Debt Ratio (R5) & 0.058 & 5.37 & 200.92 & -26.02 & 10.55 & 0.3 & 10.32 & 2.07 & 6.48 & 0.92 & 33.86 & 15.274 & 0.32 & 9.037 & 3.252 & 1.176 & Time \\
\hline Working capital ratio(R9) & 1.02 & 1.046 & 1.488 & 0.523 & 1.226 & 0.53 & 1.13 & 0.525 & 1.14 & 1.11 & 8.281 & 1.966 & 1.082 & 0.914 & 1.541 & 1.445 & Time \\
\hline Quick ratio or cash ratio(R10) & 0.9 & 0.537 & 0.638 & 0.522 & 0.416 & 0.519 & 0.85 & 0.376 & 0.44 & 1.06 & 3.014 & 1.152 & 0.588 & 0.802 & 0.974 & 1.309 & Time \\
\hline Return on shareholders' equity(R13) & $639.3 \%$ & $11.32 \%$ & $18.56 \%$ & $-6.57 \%$ & $9.4 \%$ & $-254.2 \%$ & $24.07 \%$ & $-30.1 \%$ & $-30.1 \%$ & $16.83 \%$ & $30.91 \%$ & $33.0 \%$ & $28.4 \%$ & $1117.9 \%$ & $28.11 \%$ & $13.00 \%$ & $\%$ \\
\hline Return on total assets (R14) & $-3.4 \%$ & $6.99 \%$ & $12.68 \%$ & $5.3 \%$ & $2.8 \%$ & $-9.42 \%$ & $9.68 \%$ & $-3.4 \%$ & $-3.4 \%$ & $5.97 \%$ & $18.21 \%$ & $32.1 \%$ & $21.5 \%$ & $-91.64 \%$ & $7.51 \%$ & $0.70 \%$ & $\%$ \\
\hline
\end{tabular}




\subsubsection{Comparison of Three Methods}

The objective is to find out if the three methods used in this study converge toward similarity results. The comparison of the three methods indicates unanimously that, out of the 34 companies, only 8 companies have had the best financial performances and are not likely to go on bankruptcy. The three methods have been summarized in the table 9 below.

Table 9: Comparison of Three Methods

(Z-Scores, Financial Analysis and PCA for the best 8 performing Companies)

\begin{tabular}{|l|l|l|l|l|l|l|l|l|}
\hline & GSE $^{5}$ & GSE & GSE & BRVM $^{6}$ & BRVM & BRVM & BRVM & BRVM \\
\hline $\begin{array}{l}\text { Z-Score d'Altman } \\
\text {.Financial Ratio, } \\
\text { Analysis, } \\
\text { PCA }\end{array}$ & $\begin{array}{l}\text { Enterprise } \\
\text { Group } \\
\text { Limited }\end{array}$ & $\begin{array}{l}\text { Fan Milk } \\
\text { Limited }\end{array}$ & $\begin{array}{l}\text { Ghana Oil } \\
\text { Company } \\
\text { Limited }\end{array}$ & TOTAL Ci & SPHC & $\begin{array}{l}\text { VIVO } \\
\text { ENERGY CI }\end{array}$ & $\begin{array}{l}\text { CROWN } \\
\text { SIEM }\end{array}$ & $\begin{array}{l}\text { SERVAIR } \\
\text { ABIDJAN }\end{array}$ \\
\hline Sectors & Service & Industry & Distribution & Distribution & Agriculture & Distribution & Industry & Distribution \\
\hline $\begin{array}{l}\text { Size of } \\
\text { companies }\end{array}$ & Medium & Small & Small & Large & Small & Medium & Medium & Medium \\
\hline
\end{tabular}

Source: Author's compilation

The result in the table 9 shows that out of the 8 companies, 4 were medium companies, 3 were small companies, and only 1 was large company. According to their sectors, 4 companies were in the distribution sector, 2 were in the industry sector while 1 company was respectively in service and Agriculture sector.

\section{CONCLUSION}

Bankruptcy is a legal proceeding in which a corporation has become insolvent and therefore cannot pay it obligations. The goal of this study is to assess $34^{8}$ public companies' credit risks or bankruptcy listed in two different Stocks Exchanges in the West Africa. In this light, three different model methods were used to compare their financial performance. The methods used are Z- Score of Altman, Financial Ratio Analysis, and Principal Component Analysis. As results of this study, according to the three methods, only 8 companies are safe from bankruptcy. Regarding to the discriminant function named Z- score of Altman, 15 companies have a high probability to go on bankruptcy. In other words, their financial performance were the worst among other companies.According to the remaining 11 companies, they were in the middle between distress and safe zone of bankruptcy. Managers of these companies must pay attention to the strategies they use to run up their companies and create new ones or change the existing ones in order to

\footnotetext{
${ }^{5}$ Ghana Stock Exchange

${ }^{6}$ West African Economic and Monetary Union Stock Market

${ }^{7}$ The classification was based on WAEMU Stock Exchange Capitalization's rules for all the companies

${ }^{8} 28$ companies were listed on the West African Economic and Monetary Union 'Stock Exchange, and 6 other companies were listed on the Ghana Stock Exchange
} 
improve their performance; otherwise companies will go on bankruptcy. When based on financial ratios analysis and PCA, the result is almost the same.

A cross-company financial analysis has revealed that the type of activities that each company has undertaken were different and their financial needs were different as well.

The most important weaknesses of $85 \%$ companies were liquidity problems and equity insufficiency. Among all the companies, the most best performing company was listed in Ghana Stock Exchange.

This study was the first study conducted both on the two stocks exchanges situated in the West Africa using these three methods. This work will largely contribute to the literature review and can be useful for the future researches in the same field.

The limit of this work is the difficulty to judge some companies through the analysis of the financial ratio without basing on their sector ratios. Because it was difficult to find their sector information corresponding to their year's produced financial statements. It should also be good that we use trend analysis (at least 3 years) in order to judge their real performances. More so as a limit, we can find the relative few numbers of companies that were taken account into this work. This is due to few companies that are listed in the two stocks exchanges, particularly the WAEMU's Stock Exchange.

Nonetheless, this result remains satisfactory as a whole. For the future work, other methods can be used like logistics and logit method analysis, and multidimensional analysis to show very clearly which of financial ratios and companies are closed to each other.

\section{REFERENCES}

Adalessossi Kokou and Utku. D. Burcu,(2015) Financing difficulty of Small and Medium Entreprises in West African Economic and Monetary Union Area, (edit; David publishing) China-USA Business Review, February 2015, Vol. 14, No. 2, 79-99 doi: 10.17265/1537-1514/2015.02.003

Altman E.I. (1968). Financial ratios discriminant analysis and the prediction of corporate bankruptcy. The Journal of Finance 23. 589-609.

Altman. Edward I.. "Corporate Credit Scoring Insolvency Risk Models in a Benign Credit and Basel II environment". NYU working paper. 2004.

Altman. Edward I.. R.G. Haldeman. and P. Narayanan. "Zeta-analysis. A New Model.

Aziz, A., D. Emanuel and G. Lawson. 1988. Bankruptcy prediction - An investigation of cash flow based models. Journal of Management Studies 25(5): 419-437.

Barefoot. A.S. (1996). Credit scoring at crossroads. ABA Banking Journal. June. p.26.

Beaver. W. H. (1967). Financial Ratios as Predictors of Failure. Empirical Research in Accounting: Selected Studies. University of Chicago. 1967. $71-111$.

Berger. A.N.. Klapper. L.F.. Udell. G.F. (2001). The ability of banks to lend to informationally opaque small businesses. Journal of Banking \& Finance. 25. 2127-2167.

Berger. A.. Udell. G. (1996). Universal banking and the future of small business lending. In Frame. W.. et al.. (2001). Effect of Credit Scoring on Small Business Lending. Journal of Money. Credit and Banking.. 33. 813-825.

Berger. A.N.. Udell. G.F. (2006). A more complete conceptual framework for SME finance. Journal of Banking \& Finance. 30. 2945-2966. 
Becchetti, L. and Sierra J., "Bankruptcy risk a nd productive efficiency in manufacturing firms", Journal of Banking and Finance, Vol. 27, 2002.

Bilderbeek, J., "An empirical study of the predictive ability of financial ratios in the Netherlands", Zeitschrift Für Betriebswirtschaft May 1979.

Blum, M. 1974. Failing company discriminant analysis. Journal of Accounting Research 12(1): 1-25.

Callahan; K. R; Stetz, G. S; Brooks, L. M (2007). Project Management Accounting: Budgeting, Tracking, and Reporting Costs and Profitability. Published by John Willey and Sons, Inc, Hoboken, New Jersey.

Courtis. J.K. (1978). Modeling a financial ratios categorical framework. Journal of Business Finance and Accounting. 5. 371-386.

Deakin, E. 1972. A discriminant analysis of predictors of business failure. Journal of Accounting Research 10(1): 167-179.

Dietsch, Michel and Joel Petey, "Should SME Exposures be treated as Retail or as Corporate Exposures? A Comparative Analysis of Default Probabilities and Asset Correlation in French and German SMEs", Journal of Banking and Finance 28, 2004.

Dimitras, A.I., Zanakis, S.H., Zopounidis, C. (1996). A survey of business failures with an emphasis on prediction methods and industrial applications. European Journal of Operational Research,

Edmister. R.O. (1972). An empirical test of financial ratio analysis for small business failure prediction. The Journal of Financial and Quantitative Analysis. 7. 1477-1493.

Eisenbeis, R. A., (1977), "Pitfalls in the Application of Discriminant Analysis in Business, Finance, and Economics," The Journal of Finance 32, pp. 875-898.

Emmel. A.B.. Muhittin. O.. Reisman. A.. Yolalna. R. (2003). A credit scoring approach for the commercial banking sector. Socio-Economic Planning Sciences. 37. 103-123.

Frame. S.. Srinivasan. A.. Woosley. L. (2001). Effect of Credit Scoring on Small Business Lending. Journal of Money. Credit and Banking. 33. 813-825.

Friedland. M. (1996). Credit scoring digs deeper into data. Credit World. 84. 19-23.

Frydmand. A.. Altman. E.. Kao. D. (1985). Introducing recursive partitioning for financial classification: the case of financial distress. The Journal of Finance. 1. 269-291

Gentry, J.A., Newbold P. and Whitford D.T., "C lassifying bankrupt firms with funds flow components", Journal of Accounting Research, Vol. 23, nr. 1, 1985

Glennon D.. Nigro P. (2005). An analysis of SBA loan defaults by maturity structure. Journal of Financial Services Research. 28. 77-111.

Gombola, M., Haskins M., Ketz J. and Williams D., “Cash flow in bankruptcy prediction”, Financial Management, 1987

Jacobson, Tor, Jesper Lindé, and Kasper Roszbach . "Credit Risk versus Capital Requirements under Basel II: Are SME loans and Retail Really Different?" Journal of Financial Services Research, forthcoming, (2004)

Katz. S.. Lilien. S.. Nelson. B. (1985). Stock market behavior around bankruptcy model distress and recovery predictions. Financial Analysts Journal. 41. 70-74.

Keasey, K. and R. Watson. 1986. The prediction of small company failure: Some behavioral evidence for the UK. Accounting and Business Research 17: 49-57

Laitinen. E.K. (1992). Prediction of failure of a newly founded firm. Journal of Business Venturing. 7. 323-340.

Lizal, L. (2002). Determinants of financial distress: What drives bankruptcy in a transition economy?

The Czech Republic case: William Davidson

Lo, A. 1985. Essays in financial and quantitative economics. Ph.D. dissertation, Harvard University.

Lussier. R.N. (1995). A nonfinancial business success versus failure prediction model for young firms. Journal of Small Business Management. 33. 8-20. 
Micha, B., "Analysis of business failures in France", Journal of Banking and Finance, Vol. 8, 1984.

Mossman, Ch.E., Bell G.G., Swartz L.M., and Turtle H., "An empirical comparison of bankruptcy models", The Financial Review, Vol. 33, nr. 2, 1998.

OECD Small and Medium Enterprise Outlook 2002, published by OECD Publication Services, France

Ohlson, James A. financial Ratios and the Probabilistic Prediction of Bankruptcy. Journal of Accounting Research, Vol.18, no. 1(spring, 1980), PP. 109-131.

Ooghe, H., Joos P. and De Bourdeaudhuij C., "Financial distress models in Belgium: The results of a decade of empirical research", International Journal of Accounting, Vol. 30, 1995

P Hutchinson. I Meric. G Meric (1998):The financial characteristics of small firms which achieve quotation on the UK unlisted securities market .Journal of Business Finance \& Accounting 15 (1).9-19

Platt, H. D. and M. B. Platt (1990), “Development of a Class of Stable Predictive Variables: The Case of Bankruptcy Prediction," Journal of Business, Finance and Accounting 17, pp. 31-51.

Santomero. A. (1997). Commercial bank risk management: an analysis of the process. Journal of Financial Services Research. 12. 83-115.

Saurina, Jesùs and Carlos Trucharte, "The Impact of Basel II on Lending to Small-and-Medium- Sized Firms: A Regulatory Policy Assessment Based on Spanish Credit Register Data", Journal of Finance Services Research 26, 2004

Shahzad Ijaz, UIMS-PMAS-Arid ,(2013) Assessing the Financial Failure Using Z-Score and Current Ratio:A Case of Sugar Sector Listed Companies of Karachi Stock Exchange. World Applied Sciences Journal 23 (6): 863-870

Schwaiger, Walter S.A. "Basel II: Quantitative Impact Study on Austrian Small and Medium-sized Enterprises." Technical University of Vienna (2002).

Srinivasan. V. and Ruparel. B. (1990). CGX: An expert support system for credit granting". European Journal of Operational Research 45. $293-308$.

Tam K.Y. (1991). Neural network models and the prediction of bank bankruptcy. Omega. 17. 429-445

Taffler, R J and Tishaw, H, 1977. Going,Going, Gone: Four Factors Which Predict. Accountancy, 88.

Troutt, M.D., Rai, A., Zhang, A. (1996). The potential use of DEA for credit applicant acceptance systems. Computers and Operations Research, 405-408.

Tsaih R.. Liu Y.. Liu W.. Lien Y. (2004):Credit scoring system for small business loans. Decision Support Systems. 38. 91-99.

Weston. J.F.. Brigham. E.F. (1993):Essentials of managerial finance. Orlando: Dryden Press. Zavgren, C. 1985. Assessing the vulnerability of failure of American industrial firms: A logistic analysis. Journal of Business Finance \& Accounting 12(1): 19-45.

Zopounidis. C. A. (1987): A multicriteria decision-making methodology for the evaluation of the risk failure and an application. Foundations of Control Engineering .12. 45-67. 